\title{
Africanising the Four-self-leadership Formula in the Church of Christ in Zimbabwe
}

\author{
Gift Masengwe \\ https://orcid.org/0000-0003-1222-9067 \\ University of South Africa \\ masengweg@gmail.com
}

\author{
Edwin Magwidi \\ https://orcid.org/0000-0001-6549-0280 \\ University of South Africa \\ edwinmagwidi@gmail.com
}

\section{Abstract}

The Church of Christ in Zimbabwe (COCZ) has adopted Western philosophies of Euro-American cultures originating from the Victorian age during the Restoration Movement (RM) of the American Second Great Awakening (SGA). This exclusive, divisive and oppressive culture denied women, the poor, and the young, the opportunity to lead. The RM emphasised going back to the founding charism of the New Testament Church, with Christian unity and ecumenism as central elements. Its doctrines became rigid, denying female leadership, constitutions, central headquarters, and further ministerial formation as worldly. This study raises these aspects as indispensable to the contextualising, inculturating and incarnating framework of the gospel in an African context. This reflection takes account of the four-self-leadership formula, as inspired by Magwidi's PhD study (2015-2021), as well as other sources like the minutes of church board meetings and contextual writings by COCZ's local clergy (CBACC 1948-1965; Jirrie 1972; Masengwe et al. 2012). Data were collected through semi-structured interviews that were collated with written sources and heuristically interpreted by the African Cultural Hermeneutics Approach (ACHA) (Kanyoro 2002; 2001). A synthesis of missionary ideology with African narratives of the Christian faith (using ACHA) interpreted the data to understand the "how" of contextual, cultural and religious transformation in the COCZ. The study recommends new, inclusive and transformative modes of leadership empowerment for an authentic African Church.

Keywords: Church of Christ in Zimbabwe; four-self-leadership formula; restoration theology; Victorian culture; contextualisation; Ubuntu/Unhu/Botho philosophy; autonomy

\section{UNISA $\cong$}




\section{Introduction}

This study focuses on post-independent challenges in missionary churches such as the Church of Christ in Zimbabwe (COCZ). The COCZ, according to its president's ongoing study (Edwin Magwidi 2015-2021), adopted Henry Venn and Rufus Anderson's three-self formula of self-governance, self-supporting and self-propagation without incorporating self-theologising that was later suggested by Peter Dorn (1982) and Paul Hiebert (1985) as another component to be added onto the Venn-Anderson selfleadership formula. Self-theologising was suggested by Dorn and Hiebert, but COCZ missionaries ignored it in their execution of duties, assuming autonomy was a sufficient enough term to encourage local church leaders to self-theologise. This study tries to find the relevance of the COCZ president's (Magwidi 2015-2021) proposed "four-selfleadership formula" ${ }^{1}$ (self-governing, self-supporting, self-propagating and selftheologising churches) in the COCZ's own transformation in Zimbabwe. Missionaries arbitrarily forced African churches to adopt Western concepts to buttress their ideologies of individualism, capitalism and liberalism, for instance, use of autonomy in church governance without regard for African "situated-embodied-agency." Africans, as agencies, have developed philosophies that are situated in their experiences to change bad situations, for instance: Nguni-Zulu "Ubuntu"; Nguni-Sotho "Botho"; and Shona "Unhu." It became known as an African theory/philosophy of values, ethics and morals that inform and guide Africans in contextually and practically living their faith in selfgoverning, self-supporting, self-propagating and self-theologising churches. The COCZ's total dependence on philosophies of the Victorian culture developed from British Ciceronianism and American Baconianism, which formulated capitalism, individualism and liberalism could not help (Casey 2001, 151-166). The industrial culture was deadly, in that submissiveness and domesticity were recommended for women, which later became true hallmarks of their femininity (Williams, Foster, and Blowers 2013). Men had to be aggressive outside the home, and they had to acquire power and public offices as true hallmarks of their masculinity. The Victorian culture advanced the "Womanhood Cult" that confined women to endless private and domestic life, and men to public and industrial life. True women had to be ceaselessly pious and pure; and true men daring and reckless. It excluded women from public roles, including the denial to speak at their own public gatherings, let alone assume public office. This was applauded as divinely endowed, inclusive of other forms of oppression like racial discrimination, slavery, colonialism and capitalist labour-manipulation (Williams et al. 2013). The culture was exclusive, divisive and oppressive to women; and it emphasised

1 The core of this term is self-leadership. A variation of the term the COCZ used was the "three-self formula" by Venn and Anderson: 1) self-governance; 2) self-supporting; and 3) self-propagation. The suppressed self-theologising was suggested by Dorn (1982) and Hiebert (1985) in their criticism of the Venn-Anderson three-self-leadership formula. Magwidi (2015-2021) attempts to apply both the VennAnderson three-self formula and the Dorn-Hiebert suggestion to add self-theologising by introducing the "four-self-leadership formula": 1) self-governing; 2) self-supporting; 3) self-propagating; and 4) self-theologising. Magwidi propagates that this "four-self-leadership formula" needs to be implemented in the COCZ and says that it has the aim of achieving holistic African leadership. 
male agency in a specific term, namely "autonomy." Missionaries unfaithfully implanted autonomy into the COCZ, with total disregard for the RM theologies of going back to the founding charism of the New Testament Church (Masengwe 2020). Lack of consulting New Testament teachings has led to practices that deny: 1) women to take up church leadership; 2) central church headquarter administration; 3) use of church constitutions; and 4) further ministerial formation. The Victorian culture, rather than the New Testament teachings, deprived the COCZ of fully inculturating, contextualising and incarnating the gospel. Literature used to collate data informs us that the COCZ failed to fully develop its leaders and transform its contemporary faith-narratives for the synthesis of missionary and African faith-stories; thereby enabling the church to be selfgoverning, self-supporting, self-propagating and self-theologising

\section{The Background of the Church of Christ in Zimbabwe}

The RM originated under two separate reform movements by Burton W. Stone and Alexander Campbell, who were members of the Presbyterian Westminster Confession of faith in the United States of America (USA). The RM respectively adopted the 1804 Last Will and Testament of the Springfield Presbytery; and the 1807 Declaration and Address of the Christian Association of Washington (Campbell 1995; McLoughlin 2013). They came together in 1832 as one Christian family, identifying themselves simply as "Christians" or "Disciples", and congregations as "Christian Churches" or "Churches of Christ" (McAlister and Tucker 1975, 24; Rushford 1998, 3). The RM also became known as the Stone-Campbell Movement (SCM), although we will use the RM. It called all Christians to abandon divisions brought about by creeds and church hierarchies, and to unite, work and worship together in every neighbourhood, town and village. It used shared salvation as the basis for unity, but suffered from internal doctrinal problems due to differences in the interpretation of the scriptures that led to several splinter groupings (Foster 2013, 21).

Evangelism into new lands everywhere borrowed concepts of European cities on business and politics (Weber 1978). Autonomy from the secular enterprises of capitalbusiness during the Industrial Revolution, and colonial-political administration, governed churches. Autonomy, however, was not practised by the church, but by missionaries who saw growing partnerships between the mission field and sending Western churches. The RM became an instrument of American Manifest Destiny to extend capitalism, individualism and liberalism; and denied African churches to become self-governing, self-supporting, self-propagating and self-theologising (Brouwer, Gifford and Rose 1996). Autonomy in four-self-leadership was introduced to capture a pursuit for money that offered freedom to individual (white male) pursuers. Individual men became "automatons"; hence the adoption of a social value developed in public life, namely "autonomy." Churches became male-individualised (Johnson 1975, 81); and missionaries - knowingly or unknowingly - misinterpreted autonomy for their own independence (as males among all feminised Africans) from local and foreign accountability (Weber 2009). Self-interested individuals were keen to start autonomous 
congregations according to Anglican Henry Venn and Methodist Rufus Anderson's three-self formula (Reese 2007), now the four-self-leadership formula (Magwidi 20152021). This destroyed unity, accountability, co-operation and leadership policy-making in the mission frontier (Johnson 1975, 81). Establishing an American church in an African setting further disempowered the COCZ to achieve four-self-leadership, hence it became a sitting rather than a sending church (Bosch 1991, 388). The RM principles were to restore Christian doctrine/dogma, polity, creeds and practices abused by Protestant denominations; and they wanted to change all denominations into Christian movements.

The RM was influenced by prevailing socio-economic and political traditions it had adopted in its structures. The belief in the centrality and sedimentation of New Testament Scriptures for polity and education was lost in this process. Scriptures were used to condemn denominational leadership structures and governance, and to propel individualism through the introduction of autonomy, believed to free worshippers to pursue their own vocations liberally. The motto, "Call Bible things by Bible names," led to the name "Church of Christ" (COC), found to be consistent with New Testament texts (Foster 2013, 21). These values were affected by humanism and critical thinking at the time of inclusive scientific inquiry; hence, social problems were addressed by human and social sciences during this age of inventions of the printing press, the steam engine, the spaceship and the wheel. American religion became human-centred; and the COCZ did not receive the best of those missionaries (Jirrie 1972, 1-21).

There were more New Zealander, Australian and American lay missionaries, compared to clergy, who came to Zimbabwe with their own national persuasions. Different missionaries were interdependent but contested on values like congregational autonomy and regional oversight, which mark continuities and discontinuities in the COCZ (Weber 2009). Autonomy (which many locals interpreted as an African church with strong links to churches in originating countries), minimised how locals shared leadership functions with missionaries, denying the local church from functioning as an autonomous church, led by both local and foreign Christians (Reese and Wimon 2001, 69). Dependent African church leaders became disoriented emotionally and economically (Maxwell 2013, 7-102). Wanton condemnation of clericalism in favour of lay-leadership could not reconcile the thoughts and aspirations of founders with ordinary Africans. Local churches failed to develop laws, policies, resources and faith practices, which led to a crisis in the post-missionary COCZ. The post-missionary COCZ acquired land to construct its own church headquarters for purposes of local administration (in the Midlands Province, South of Gweru, at Somabhula, in the Lukuluba Rural Community), that revealed past problems during the missionary era (Masengwe and Chimhanda 2020, 1-10). The COCZ's authentic transformingmissional path was done through the Somabhula Conference Centre Construction, constitutional reform (COCZ 2015) and further ministerial formation, which attempted to rewind the sacralised missionary historical wrongs (Masengwe and Chimhanda 2019, 1-11). This change has considered gender equity in church leadership, and is currently 
struggling to fit female church ministers in congregations (Masengwe, Chimhanda, and Hove 2019, 278-289). This paper argues for a contextually informed COCZ, guided by its own laws to achieve its goals (Johnson 1975, 70) without foreign domination in its programming, theologies, resources and growth.

\section{White Leadership Superiority in the Zimbabwean Protestant-Colonial Church}

Protestant missionaries, from different denominations and missionary societies, coincidentally arrived in Zimbabwe in large numbers at the onset of the colonial escapade in the late 1890s, in a strategy to use the church in paving the way for a successful colonial enterprise (Banana 1996, 20). Colonial Christianity was developed after the 1884 African partitioning conference at Berlin (Kealotswe 2016, 43). Protestant churches turned away from their conflict at home (in Europe), to be used for colonial politics that did not teach about total liberation and salvation for Africa (Kealotswe 2016, 43). Rather, they discriminated against and despised African customs and values in favour of Western European cultures, and had the habit of claiming to have discovered uninhabited lands, world wonders and world treasures (Kealotswe 2016, 43). This misconception treated Africans as sub-humans or savages, hence the missionaries aimed at erasing the cultures of indigenous people in the new lands, or "brainwashing" them to abandon their civility and sophistry - as if that did not exist (Moyana 2017, 45). This attitude was upheld by almost all missionaries of Protestant missions.

English white men felt that they were carrying out God's divine plan in Africa, to "spread Justice, Liberty and Peace ... over the widest possible area of the planet ... to make the world English" (Thomas 1997, 114). Rhodes (in Thomas 1997) personally stated that: "I contend that we are the finest race in the world, and that the more of the world we inhabit the better it is for the human race ... Added to this, the absorption of the greater portion of the world under our rule simply means the end of the wars" (Thomas 1997, 100). The belief that capitalism, colonialism, and Christianity were bringing justice to an unjust African society, freedom to African people and peace in an ever-warring Africa, was also engraved in the superiority complexes of the church, as much as they were for fortune-seekers and colonialists. To advance colonial interests, Rhodes used the press, for he believed it ruled human minds (Thomas 1997, 112-113). To achieve justice, liberty and peace, colonialists believed Africans had to be subdued (Thomas 1997, 110). Settlers, capitalists and missionaries were equally filled with notions of white supremacy; they established white-master-to-black-servant relationships, and the obtrusive and "retrogressive institution was to be upheld and adhered to tenaciously by the settler community" (Banana 1996, 20). Rhodes' ideology was that Africans were not to be treated as citizens, but as a subject-race through class legislation, and that whites were to be their lords everywhere (Samkange 1982, 15; 1980). Fellow whites who adopted this ideology treated Africans as children and subhumans who could not govern themselves (Banana 1996, 36; Thomas 1997, 99). The 
law, morality, religion, education, art and science were guided by this ideology, negating the values of justice, peace and liberty. Ideology, being useful for legitimising "the power of the ruling class" and their "dominant ideas" (Eagleton 2002, 5) became conflicted. European Christianity became colonised as much as it contained the warped Victorian culture. Protestant missionaries operated amphibiously in and out of the white community, as the church was part of the colonial enterprise; to extend the dominant culture (Banana 1996, 33, 40).

Protestant missionaries adopted the separation of white and black Christians, where white churches were well resourced and blacks who attended the "white" churches, were better treated compared to those who attended African congregations. Colonialism was rife in churches, as the missionaries worked under the "dominant Rhodesian colonial racist ideology" (Banana 1996, 33) that represented European values, and Africans could not lead or run churches until the rise of militant African nationalism. The COCZ functioned under the same racist ethos that produced a distorted sense of white selfimportance and black self-rejection (Banana 1996, 33). Lack of equality in the COCZ affected its ability to pursue self-governance, self-support, self-propagation and selftheologising, as European values were not only perpetuated but overtly protected (Kealotswe 2016, 4). African converts had to be Europeanised/Americanised at the church's educational and health centres. While some missionaries, like Sir Garfield Todd, resisted the colonial ideology in their mission stations (Chigwedere 2017; Woodhouse 2018), others internalised the colonial attitude that controlled colonial evangelisation to achieve colonial economic and power interests (Kealotswe 2016, 44). Protestant missionaries who had good intentions for Africans became frustrated and victimised by the colonial government (Kealotswe 2016, 44). Protestant missionaries who failed to raise resources for their work became tempted to join the colonial bandwagon for their missions to survive (Kealotswe 2016, 44). Garfield Todd also joined politics to advance African interests rather than personal survival (Chigwedere 2017; Woodhouse 2018).

This study concerns leadership succession in the COCZ, which was set into motion during the colonial era. COCZ missionaries did not seriously consider African leadership and culture as vital elements in the white packaging of the church's future (Banana 1996, 34). This began with inequitable resource distribution across church organisations, wherein the "undercurrents of cultural, linguistic, racial and class diversity wash away any opportunities for interracial cooperation in churches" (Banana 1996, 35). Missionaries, like colonialists, competed with African Christians for "They also saw the advancement of the African people as a threat" (Banana 1996, 35). The irrational fear of blacks destabilising "European fortresses of long-established comfort and traditions" (Banana 1996, 35) divided COCZ New Zealand and American missionaries (Banana 1996, 33). The colonial government gave mission stations grants to aid foreign donations, hence supervision and reporting on COCZ mission administration were done by white ministers who superintended/supervised blacks and not vice versa (Banana 1996, 57). "Indeed, it was commonplace for European 
missionaries, immediately on ordination to be made superintendents of circuits, and African ministers most of them many years their senior, appointed as assistants" (Banana 1996, 59). Because of this orientation, Bakare (1993) says:

The Western oriented churches of Africans tend to have the same ecclesiastical structures and doctrines as their mother churches in Europe and North America. The Western missionaries who founded many of these churches in [the] 19th century had a generally negative attitude towards African cultures and thought forms; thus, African converts to Christianity were expected to give up their own cultural ways and put up a Western culture. (Bakare 1993, 15)

Missionaries insisted on Africans giving up their own traditional cultural practices for traditional cultural practices (Bakare 1993, 15). In the COCZ, this changed from Protestant doctrinal fights to political contestations (Kealotswe 2016, 44) that forever divided the denomination on the land, with some following the American conservative wing under Nhowe Mission (in Mashonaland East), and others under Mashoko Mission in Masvingo, while the New Zealanders retained Dadaya Mission in Midlands, Zvishavane (CBCC 1948-1965). The missionary leadership challenge with leadership has affected the post-missionary church, as $\mathrm{COCZ}$ missionaries originated from the era of American democracy and developed differently in the USA, New Zealand and Australia, with a varying appreciation of ethnicity, dehumanisation and racial supremacy in the frontier. This, however, did not affirm African participation to achieve four-self-leadership during their time in Zimbabwe. Missionary departure in the late 1980s in Zimbabwe left a leadership vacuum in mission station management (Magwidi 2015-2021); Christian identity/doctrine; Christian mission and church polity (Masengwe and Chimhanda 2019, 1-10; Masengwe 2020), including the consideration of female ministers in congregations (Masengwe, Chimhanda, and Hove 2019). The COCZ currently struggles to unite on conference centre construction, constitution making and further ministerial formation (Masengwe and Chimhanda 2019, 1-11) because missionaries did not prepare members to self-govern, self-support, selfpropagate and self-theologise. With the COCZ emphasis on going back to the roots:

... the core of the Christian faith as taught by Jesus Christ, expounded by Paul and lived by the early Church [up] to AD 313, had never been taught to the Africans. The Africans need to go to the crossroads to find the core teachings and beliefs of Christianity as a religion distinct from others. (Kealotswe 2016, 44)

Mofokeng's thesis, "The Crucified among the Cross-Bearers: Towards a Black Christology" (1983) strengthens this argument. The person of the crucified Jesus, who is black, brings the discourses of salvation in contemporary African discourses to be authentic. This includes the role of a black Virgin Mary and other blacks who played significant roles in the burial of Jesus - if they are done appraising the role of the African race in the person of Jesus, and the cult of a black Virgin Mary. This contrasts with how missionaries treated Africans in running the church in southern Africa. Africans were considered illiterate; hence they were not given any manuals, policies, 
practices and teachings on church polity, mission, doctrine, mission centres and leadership succession. Christianity rather deviated from the basic teachings of the Bible; centred on Christ as believed in the COCZ, and the practice of love for the marginalised (women, children, minority races and ethnicities) as a yardstick for the true faith. This study purposes at finding how the COCZ is trying to contextualise itself by including women and children into the mainstream Christian community by centring their participation in the church.

\section{Leadership Succession in the Church of Christ in Zimbabwe}

The COCZ disagreements emanate from "who" and "how" its institutions are led and managed after the departure of missionaries (Masengwe and Chimhanda 2019, 5). Missionaries did not consult, converse or seek consensus with local leaders in many of the activities they carried out. At the departure of missionaries, those who worked closely with them considered mission stations their ministry-pensions. Schools and hospitals were taken as personal and family projects, and began to be treated as family enterprises. Missionaries managed because they had resources, but the post-missionary managers have run them down, as they take away the resources from the entities rather than investing in them (Magwidi 2015-2021). Institutional autonomy means that new leaders are implanted as older leaders retire, resign, die or become insolvent (Mamprin 2002, 2-3). This affects leadership effectiveness, as the transition processes lack consensus, recognition, acceptance and support. The link of the incumbent with early COCZ missionaries is highly respected; and emphasis is given to legacy and dis/continuity. Most incumbents, unfortunately, lack authenticity due to lack of grooming, which leads to higher worker turnover that destabilises institutional history and memory (Mamprin 2002, 2-3). Great leaders, though, consider themselves dispensable, and their role is to ennoble others to serve institutions and communities when they retire (Kalungu-Banda 2006, 108). Leadership preparation, development and management in the COCZ has failed to guarantee continuity (Kalungu-Banda 2006, 108) because no pool of leaders has been developed to continue with the work. Authoritarian leadership impacted negatively on skills development, staff retention, talent management and succession policies, as it used the right of primogeniture (hereditary-type of governance). Hereditary-types do not consider personal qualities, as Hannah Arendt says "the will of the Fuehrer is law" (Kellerman 2014; Kohn 2007). It trains every person in the hierarchy to achieve a single purpose, and to effectively communicate the will of the leader to the people. Such a leader cannot be replaced because the whole organisation is a complicated structure upon which losing the leader, the whole "movement would lose its raison d'etre." Such leaders are secure from palace coups, revolutions or rebellions. They have superior gifts upon which their followers sincerely and sensibly give full allegiance because the loss of the leader is the loss of everything they had hoped to achieve (Kellerman 2004; 2005).

The COCZ has had similar challenges, despite the fact that long-term success in visionary organisations results from a "focus on succession, planning and leadership 
development" (Kalungu-Banda 2006, 108). Successful businesses cultivate, support, and carefully choose the best from available talent to ensure excellence and continuity in leadership, management and administration. Missionaries failed to deliberately identify, assess and develop talented leaders to ensure mission continuity and strategic development, but they isolated themselves from potential African leaders as they did not foresee an immediate departure (Kalungu-Banda 2006, 108). They did not leave the centre stage in time and wind up their business to allow new potential candidates to smoothly emerge as they became ennobled for transitions instead of cloning themselves (Kalungu-Banda 2006, 124). COCZ institutions suffer from operational gaps because new leaders attempt to be like their missionary godfathers/godmothers. Use of arbitrary leaders in the COCZ undermined due to lack of leadership grooming, and hence leadership grooming. The COCZ missionaries who came during the colonial era adopted "autonomy" as their operational philosophy, a corporate sector approach of the time in their own countries and can no longer apply to a postmodernist African church. Such a law needs to be interrogated in order to resolve disputes and disorder in the COCZ. Businesses that achieve legacy and continuity begin with clear purposes. Purposes are supported by values that are communicated and incarnated at every level of service provision to give a sense of pride to the business partners and workers who have "a sense of common ownership" in organisational position and products (KalunguBanda 2006, 124). Leadership tasks, rather than titles, matter most. Human beings are honoured to be representing God's image. This enables and ennobles others, because greatness is contagious; it raises pride and confidence in followers whose self-worth is respected. Missionaries (during the colonial era) denigrated African leaders, who in turn are denigrating those who are supposed to learn from them (Kalungu-Banda 2006, 124).

In Africanising leadership in the COCZ, and in exploring how to achieve four-selfleadership, African philosophy and values will be introduced in this paper. The stipulation of the RM principles in an African church can address the autocracy practised by missionaries. This enables the COCZ to optimise African philosophy and its RM founding charism. This recovers $\mathrm{COCZ}$ authenticity to administer itself, and to serve its followership through a series of leadership development processes and programmes.

\section{Enock Jirrie and Africanising the Church of Christ in Zimbabwe}

Contextualisation in the COCZ has for long been discussed among clergy and laity. The earliest, significant written reflection was done by a church minister, Mr Enock Jirrie, in a 20-page monograph, How to Uproot Church Problems (1972). The booklet, a graphically designed memorandum to the white missionaries, was used in informal settings as missionaries suppressed its contents, but in contemporary times it is a classic COCZ document on leadership, identity, worship and local ownership/control of the church.

White American lay missionaries were unprofessional, and came as doctors or teachers, with enthusiasm for spiritual matters, which they failed to correctly handle in an African 
context. They used distractive and divisive approaches. They lacked leadership qualities and biblical practices to inculcate their vision upon local leaders. The church was left without a plan for the future. At independence they failed to raise trusted clergy, as they trusted secular professionals to lead the church - for they were mostly lay. Lay leaders considered church ministers as their employees. Jirrie had tried to avoid this by calling for religious and theological reform to prepare for the post-war era. Missionaries psyched up their employees to sabotage this call as threatening to the RM principles (Masengwe 2020,73). This led African ministers to work in small and unfriendly units under missionary surveillance. Jirrie (1972) condemns this inconsistency as disillusioning and creating competition on the mission field. Co-workers could not share experiences and success stories due to paternalism; where missionaries became towers and symbols of dignity and importance in the church. This was the genesis of problems in the COCZ. In transforming itself, it has struggled to keep abreast with developments in the country because missionaries did not look beyond their time to recruit competent local leaders to coordinate the work. Jirrie (1972) argues that no church in history succeeded without coordination and cooperation, because the necessary conditions are needed to make congregations autonomous entities, rather than divided churches under the disguise of autonomy. He states: "Indeed, coordination must still be regarded as an eventual corner of the Lord's work" (Jirrie 1972, 14).

The booklet of Jirrie (1972) is worth reflecting on, as it sets the sentiment for what John Pobee 20 years later (1992) and Robert Reese 30 years later (2001) concur with. Western thinking dominated the white-led church, hence Jirrie (1972) argued that competent leaders from among black congregants should be raised to take over from missionaries. The Todd family tried to heed this, and in fact had been doing it since they came to Zimbabwe in the early 1930s, but Americans who came in the middle-1950s, did not. Robert Reese concurs with Jirrie in Masengwe that "Africans needed to take up leadership in order to wean the African Church from its Western tutelage into a fullyfledged African Church" (Masengwe 2020, 74) because God did not want "Africa to be a mission Church under the perpetual care and tutelage of missionaries" (Reese and Wimon 2001, 86); but to be a missionary church led by African leaders to reach out and finish the great work of reconciling the world to Christ. This is what a sensible missionary, who prepared for retirement in advance, and who was a contemporary of Enock Jirrie, David Grubbs $(2009,211)$ calls "passing on the baton into the hands of the African leaders." He further states: "Even then, with war looming on the horizon, we dreamed about the day when Mashoko mission would be completely under the leadership of African doctors, teachers, preachers, and technicians" (Grubbs 2009, 211). This was also the dream of Garfield Todd at Dadaya, even though historical events did not offer the expected outcome (Chigwedere 2017; Woodhouse 2018).

Jirrie, in his writing and other reflections, remained consistent with his 1972 message, where he raised pertinent questions for evangelical Protestantism. Social action was a means for preaching the gospel. COCZ missionaries beneficially embraced it through the construction of mission stations to educate locals in basic education and agricultural 
skills training, handcrafts and basic health care. Basic education was good for church leaders to reflect on their agency in the church through the four-self-leadership formula. Inculturation theology emanated due to this reflection when the church in Africa began to cooperate with "nationals to remove colonialism and to restore human identity and dignity to the black African person" (Masengwe 2020, 74). Good examples of these contextualisation examples in the Catholic and Anglican churches across Eastern and Central Africa encouraged Christians in Southern Africa to engage in theological and social reform. For the COCZ, Jirrie's work "marked the beginning of the desire to continuously transform the Church in line with the social contexts of the moment" (Masengwe 2020,75), despite the church's inadequate theological arsenal and money to transform itself, as it depended on foreign support. Jirrie's work threatened lay missionaries who declined to restore dignity and identity to African Christians by bestowing leadership authority and authenticity on them. This denial led to a leadership vacuum in the post-missionary church. The post-missionary splits due to constitutionmaking, conference-centre construction, further ministerial formation, and gender inclusion in the ministry for church growth, are evidence of failure to be self-governing, self-supporting, self-propagating and self-theologising. This was caused by missionaries' selfish manipulation of the capitalist, liberalist and individualist Victorian culture and philosophy.

\section{"Ubuntu/Unhu/Botho" in the Church of Christ in Zimbabwe}

The use of "Ubuntu/Unhu/Botho" which "can be described as a social philosophy" (Ncube 2010,78), is a concept, theory, philosophy and practice that encapsulates the African worldviews that influence social conduct, and "represents personhood, humanity, humanness, and morality" (Brack et al. 2003, 316-326). Rukuni asserts that Unhu-Ubuntu-Botho is "being human, is a way of life ... is a time-tested way of building yourself as a person and human being ... is also a time-tested way of building family and family processes ... is the only time-tested way of building communities and nations" (Rukuni 2007, 142). It is "the entry point and end point of all the various pathways leading to God" (Rukuni 2007, 143); "It is a way of life and stresses the importance of community, solidarity, sharing and caring" (Nzimakwe 2014, 30). It is a "cultural worldview that sustained Bantu-African communities for many centuries and captures the essence of being human" (Mnyaka and Motlhabi 2005, 215; Murithi 2009, 221-233; Ntibagirirwa 2009, 10; Ramose 1999, 300), "anchored in its own person, culture and society, which is difficult to define in a Western context" (Karsten and Illa, 2001, 91-110). This Bantu-centric principle "invokes traditional cultures" (Ncube 2010, 78), and has a different understanding of leadership and leadership succession principles, as it "is the capacity in the African culture to express compassion, reciprocity in the interests of building and maintaining community" (Nussbaum 2003, 21). It represents an African renaissance that prioritises leadership development for the service of humanity. Ubuntu/Unhu/Botho thus, may be defined as "an all-inclusive, deep-rooted African world-view that pursues the primary values of intense humanness, caring, sharing and compassion, and associated values, ensuring a happy and qualitative human 
community life in a family atmosphere and spirit" (Fox 2010, 124); that embraces a caring spirit for individuals and community, for harmony and hospitality, for respect and responsiveness (Mangaliso 2001, 23-33). It emphasises reciprocity and sharing; universality and brotherhood; and treats others with respect and dignity. It, therefore, encourages cooperation and interconnectedness/interdependence, by prioritising and stressing human dignity, safety, welfare, health, love and development before political, financial, and economic factors (Ncube 2010, 81).

African philosophy can be understood on the basis of Mbigi and Maree's (1995) "African Tree" concept, where leadership was built on connection, membership, duty, talent and collectivism (Malunga 2009). Material things do not supersede being human, which inspires individuals to trade their abilities with others in order to meet corresponding differences that inform and enrich one's humanity. Through other people one finds own full humanity; hence as the philosophy is translated "Umuntu Ngumuntu Ngabantu," it means: "To be human is to affirm one's humanity by recognising the humanity of others in its infinite variety of content and form" (Van der Merwe 1996, 1). This recognises respect for particularity, individuality and historicity (Louw 1998). To be a person illustrates humanness only found in the "collective" rather than the "individual." It recognises the genuine otherness and diversities of peoples, languages, histories, and cultures in post-colonial societies (Louw 1998). This requires a common criterion to judge, without violating the affairs of others (Louw 1998).

Autonomy in the COCZ advanced isolation, which is not virtuous. Sound relationships are a trademark of African philosophy - hence the use of participatory, transparent, and democratic processes. Relationship-building leads to interconnectedness, collaboration, collectivity, reciprocity, trust and empowerment. By empowering others, Africans emphasise to strengthen them to act in their own stead (Ncube 2010, 80). On sharing burdens and benefits, Nussbaum says, "your pain is my pain. My wealth is your wealth. Your salvation is my salvation" (2003, 21). This study explores how Ubuntu/Unhu/Botho philosophy can inform and advance leadership and governance in the COCZ, where there is a desperate need for local and progressive leadership in an age of innovation, entrepreneurship and democracy. "The emergence of Ubuntu as a leadership philosophy is not meant to replace Western leadership philosophies but to add to the diversity and richness of the discourse" (Ncube 2010, 81). This is because most African philosophies are inclusive, syncretic and accommodative, hence progressive.

In an age of new developments, this) philosophy of leadership (Ubuntu/Unhu/Botho maybe rendered inadequate (if applied alone), due to written laws and policies, a diversity of cultures and a host of technological and technical changes across the globe. However, it can be applied to leadership transformation by allowing churches to adjust according to global developments. Naturally, the African social culture is collectivist, which encourages cooperation and unity (teamwork) in building individual and community loyalty and solidarity (Ncube 2010, 81). The COCZ lacks cooperation, 
loyalty, solidarity, unity and success, as seen in the reaction to the first constitution of the COCZ, the adoption of the Somabhula Conference Centre and further ministerial formation, including the acceptance of female ministers into the churches (Masengwe and Chimhanda 2019, 1-11). Despite a desperate need for indigenous, innovative, valued-based leadership approaches in the COCZ (that could mobilise members towards a common goal of evangelising, making disciples and engaging in social action), new developments have led to a split (Bekker 2007). The ability to cross-pollinate Ubuntu/Unhu/Botho with Eastern and Western/Northern philosophies, makes it a progressive philosophy for change and well-being in Africa (Ncube 2010, 81). This empowering humane-principle that uses collectivity, "solidarity and community rather than individualism and particularity" (Nzimakwe 2014, 30), can cultivate leadership innovation and excellence found in human potential; it can develop and empower people to grow and embrace new opportunities for their organisations (Ncube 2010, 81).

Ubuntu/Unhu/Botho has been viewed as a post-colonial paradigm of leadership that embraces the discourse of inclusivity. It appropriately places leadership structures that are relevant to African contexts in cooperative, inclusive, diverse, and unity for religious, cultural, racial, tribal and political groups (Mbigi 1996, 8). "Legitimacy of leadership is therefore a function of relevance and acceptability within a culture and or situation rather than the function of a process such as elections" (Rukuni 2007, 169). Thus, electing church leaders alone is inadequate and insufficient to legitimise and authenticate a leader for selection, appointment, inheritance or rotation in a work situation. Christian leaders are, therefore, expected to understand the significance of interdependence, morality, spirituality and universality for the effective management of their institutions. With the doctrine of autonomy in the COCZ, respect for individuals must be counterbalanced with respect for communities, where teamwork and solidarity help in achieving individual aspirations.

\section{Problematising Ubuntu/Unhu/Botho in African Leadership}

A critique of African philosophy begins with the failure of African leaders to embrace the theory in their leadership cultures, with the exceptions of first presidents of independent South Africa (Nelson Mandela) and Botswana (Sir Seretse Khama), who embodied African philosophy as demonstrated by their traditional values. Other African leaders became dictators, and other African hosts killed their African visitors through xenophobic attacks — as will be shown below (Malunga 2009).

\section{African Dictatorships and African Philosophy}

Dictatorship was originally used to describe the temporary suspension of established rules during war (Irele 2007). Contemporary dictators create exclusionary power structures that benefit a few by forcefully disregarding the written rules of participatory democracy. Dictators are totalitarian and authoritarian governors. They superintend political systems that subvert agreed norms and values. Post-colonial Africa experienced military and civil dictators, and a total recorded 86 military coups between 
1956 and 2002. Military dictators, like Ugandan Idi Amin, Zaire's Mobutu Sese Seko, Sierra Leone's Samuel Kanyon Doe, and Nigerian Sani Abacha, alternated with civilian dictators like Malawian Hastings Kamuzu Banda, Equatorial Guinea's Francisco Macias Nguema, and Zimbabwean Robert Mugabe. Dictators justified themselves by citing that national integration had to be preserved in modernising the state. Unfortunately, governments obtained and retained power illegally, using and abusing difference to purchase loyalty. Dictators are more vulnerable and insecure, hence need more power to subvert legal and constitutional provisions (Irele 2007). This questions the substance and tenability of African philosophy that fails to make Africa the breeding ground for democracy (Ramose 2010), as Ubuntu/Unhu/Botho by nature is human rights oriented. If it is to become a true reflection of African moral condition, it needs to be re-evaluated because the numerality of dictators in Africa renders it a generally misconceived philosophy - as most do not consider their fellow African citizens. Mandela, in his own statement and vision, displayed this philosophy in 1964, while in prison, and at the opening of his defence case on 20 April 1964, which he ended stating: "I have fought against white domination, and I have fought against black domination. I have cherished the ideal of a democratic and free society in which all persons live together in harmony and with equal opportunities" (Irele 2007). This makes African philosophy a viable alternative theory based on a framework of African experiences (Irele 2007).

\section{Afrophobia and African Philosophy}

Most African economies are underdeveloped, and have high rates of unemployment and poverty. When Africans go into neighbouring countries in search of greener pastures, expecting to be warmly welcomed, they are attacked by fellow Africans, which contradicts that Ubuntu/Unhu/Botho is an African worldview. If it fails to apply to Africans among themselves, it becomes difficult to apply among people of non-African origin. Xenophobia as an unreasonable fear, distrust, or hatred of strangers or foreigners can manifest itself in several ways such as police brutality, street assaults, social murders, ethnic fights and mass expulsions from a country (Louw 1998). Afrophobia, like what happened in South Africa recently, is an unreasonable fear, distrust or hatred of African visitors by African nationals who act violently against such foreigners in their midst, inclusive of those with legitimate permits and visas, and those who acquired citizenship by virtue of their skills such as medical doctors, engineers, scientists and academics. Such African countries begin to blame other African countries for drug peddling, human trafficking, crime, unemployment and disease (Louw 1998). These attacks by Africans on other Africans have been cited by some scholars as evidence for the non-existence of Ubuntu/Unhu/Botho (Qobo and Nyathi 2016).

\section{Leadership Theory in African Philosophy}

The relevance of Ubuntu/Unhu/Botho for servant leadership among black South African leaders was investigated and broadly accepted by Nelson (2004), using Patterson's factors. It strongly corresponds with servant leadership, despite Patterson's verbal 
enthusiasm for the model and its applicability in South Africa (Nelson 2004). However, factors like low trust, ineffective empowerment and negative connotations of a "servant" hinder its use in South Africa (Winston 2007; Bekker 2010). These concepts relate to power and a mind-set that contrasts Western concepts of power for their use in South Africa (Winston 2007; Bekker 2010).

\section{The Future of Leadership in the Church of Christ in Zimbabwe}

The COCZ received the RM principles at its inception in the late 1890s, but the governing ideology - autonomy-was introduced and nurtured by the American conduit that took centre stage in the mid-1950s at Mashoko Mission, which extended to Devure and Chidamoyo Mission Stations (Masengwe 2020). Americans were most aggressive, innovative and daring in the frontier, being able to divide churches and start missions that followed divisional traditions in the USA along three groups: Churches of Christ (non-instrumental), Christian Churches/Disciples of Christ (instrumental), and United Churches of Christ (international). These divisions and lessons are a platform upon which African COCZ leaders gave meaning to their people, as they refused to be passive onlookers to a divided church in a modernised-machinised world (Bakare 1993, 15). Missionaries did not live what they taught, and Africans wanted to follow the biblical principles of the RM by going back to their founding charism (Masengwe 2020). The Bible, as the founding charism, is the "crossroad" or starting place for the Christian journey, which requires one to re-read and re-interpret the scriptures to establish an African Christian church as found in the gospels (Kealotswe 2016, 51). A transformed church tolerates differences of sex, gender, tribe, ethnicity, race and class, like Jesus tolerated the Jews, heathens, prostitutes, tax collectors, the rich, poor, women and children, discriminated against by Jewish, Greek and Roman laws. The idea of a cross-roads here represents signposts to give travellers direction. The Bible is that starting signpost for all sojourners to trace and retrace their paths in their Christian walk or leadership. When the Bible is interpreted in light of indigenous and foreign cultures, it paves the way for reconstructing new theologies, church-support systems, organic church growth, and indigenously relevant governance processes. The four-selfleadership formula can construct inclusive theologies for the COCZ to rewrite biblical teachings that transform leaders, laws and worship (Kealotswe 2016, 51). The RM principles can thus be contextualised and applied in the COCZ to achieve evangelism, discipleship and church growth.

\section{Conclusion}

The COCZ has failed to achieve four-self-leadership, because it did not interchange Western and African cultures in transforming the gospel into an African context. It failed to address racial supremacy, gender discrimination, denigration of the poor, and ethnic superiority. This could have been used for the continuity of leadership and mission in the COCZ, as taught by Jesus Christ that a leader must be a servant of all people. The RM founders valued leadership for institutional legacy and continuity, as they did in their founding documents. In using African philosophy, the 
Ubuntu/Unhu/Botho theory can be utilised to transform authoritarian leadership in the COCZ through consensus-building. This will consider the plight of women ministers who should fully enjoy the preaching profession. This paper has also presented the challenges that the COCZ faces with its colonial history and development, especially the embracing of Western culture and the suppression of indigenous cultures and traditions to support its leadership development processes and programmes.

\section{References}

Bakare, S. 1993. My Right to Land in the Bible and in Zimbabwe: A Theology of Land for Zimbabwe. Harare: Zimbabwe Council of Churches.

Banana, C. 1996. Politics of Repression and Resistance: Face to Face with Combat Theology. Gweru: Mambo Press.

Bekker, C. J. 2007. Dreaming with Open Eyes: Reflections on Leadership and Spirituality. Regent University, School of Global Leadership and Entrepreneurship. https://doi.org/10.1057/9780230299184_5.

Bekker, C. J. 2010. “A Modest History of the Concept of Service as Leadership in Four Religious Traditions.” In Servant Leadership, 55-66. London: Palgrave Macmillan.

Bosch, D. J. 1991. Transformation of Mission: Paradigm Shifts in Theology of Mission. Maryknoll: Orbis. https://doi.org/10.1177/009182969101900203.

Brack, G., M. B. Hill, D. Edwards, N. Grootboom, and P. S. Lassiter. 2003. “Adler and Ubuntu: Using Adlerian Principles in the New South Africa." Journal of Individual Psychology 59 (3).

Brouwer, S., P. Gifford, and S. D. Rose. 1996. Exporting the American Gospel: Global Christian Fundamentalism. New York: Routledge

Campbell, A. 1995. "Foundation of Christian Union.” Restoration Quarterly 37 (1): 1-26.

Casey, M. W. 2001. "From British Ciceronianism to American Baconianism: Alexander Campbell as a Case Study of a Shift in Rhetorical Theory." Southern Communication Journal 66 (2): 151-166. https://doi.org/10.1080/10417940109373194.

CBACC (ColenBrander Avenue Church of Christ). 1948-1965. Minute Book [1948-1965]. Bulawayo: CBACC.

Chigwedere, A. S. 2017. The White Heroes of Zimbabwe: John White, Arthur Shearly Cripps, Reginald Garfield Todd, Jean Grace Todd. Harare: Mutapa Publishing House.

COCZ (Church of Christ in Zimbabwe). 2015. The Constitution of the Church of Christ in Zimbabwe. Somabhula: Somabhula Conference Centre. 
Dorn, Peter. 1982. “The Three-Self Principle as a Model for the Indigenous Church.” Masters of Divinity Thesis. 17. http://scholar.csl.edu/mdiv/17.

Eagleton, T. 2002. Marxism and Literary Criticism. Psychology Press. https://doi.org/10.4324/9780203361771.

Foster. D. A. 2013. The Story of Churches. Abilene: Abilene Christian University Press.

Fox, W. 2010. A Guide to Public Ethics. Juta.

Grubbs, A. D. 2009. The Partridge Principle a Memoir of Life in Zimbabwe. Cincinnati Christian University, Cincinnati.

Hiebert, P. G. 1985. Anthropological Insights for Missionaries. Baker Book House.

Irele, F. A. 2007. "The Political Kingdom: Toward Reconstruction in Africa." Socialism and Democracy 21 (3): 5-35. https://doi.org/10.1080/08854300701599791.

Jirrie, E. 1972. How to Uproot Church Problems. Harare: Weaver Press.

Johnson, H. E. 1975. The Christian Church Plea. Cincinnati: Standard Publishing.

Kalungu-Banda, M. 2006. Leading like Madiba: Leadership lessons from Nelson Mandela. Juta.

Kanyoro, M. R. A. 2001. "Cultural Hermeneutics: An African Contribution,”101-113. In Other Ways of Reading: African Women and the Bible, edited by M. W. Dube. Atlanta: Society of Biblical Literature.

Kanyoro, M. R. A. 2002. Introducing Feminist Cultural Hermeneutics an African Perspective. London, New York: Pilgrim Press.

Karsten, L., and H. Illa. 2001. "Ubuntu as a Management Concept.” Quest: An African Journal of Philosophy 15 (1-2): 91-110.

Kealotswe, O. 2016. “African Christianity in Colonial Times. In Anthology of African Christianity, 43-52, edited by I. A. Phiri, D. Werner, K. Owino and C. J. Kaunda. Regnum Books. https://doi.org/10.2307/j.ctv1ddcqdc.18.

Kellerman, B. 2004. Bad Leadership: What it Is, how it Happens, why it Matters. Harvard Business Press.

Kellerman, B. 2005. “How Bad Leadership Happens.” Leader to Leader (35):41. https://doi.org/10.1002/ltl.113.

Kellerman, H. 2014. "Hitler and Genocide." In Psychoanalysis of Evil, 71-108. Springer, Cham. https://doi.org/10.1007/978-3-319-07392-7_6. 
Kohn, J. 2007. “Totalitarianism: The Inversion of Politics.” Three Essays: The Role of Experience in Hannah Arendt's Political Thought. Hannah Arendt Centre, New School University. https://memory.loc.gov/ammem/arendthtml/essayb7.

Louw, D. J. 1998. "Ubuntu: An African Assessment of the Religious Other.” Paper presented to 20th World Congress of Philosophy, Boston, Massachusetts, USA, 10-15 August. www.bu.edu/wcp/Papers/Afri/AfriLouw.htm.

Magwidi, E. 2015-2021. "Leadership Succession in Church and Mission: A Comparative Study of the Succession Processes between the Dadaya and Mashoko Missions from 19562015." PhD candidate research topic. Department of Church History, University of South Africa, Pretoria.

Malunga, C. 2009. Understanding Organizational Leadership through Ubuntu. Adonis and Abbey Publishers.

Mamprin, A. 2002. Five Steps for Successful Succession Planning. Executive Update. https://scholar.google.com/scholar?hl=en\&as_sdt=0\%2C5\&q=Mamprin $\% 2 \mathrm{C}+\mathrm{A} . \% 2 \mathrm{C}+200$ 2.+Five+steps+for+successful+succession+planning.+Executive+Update.\&btnG $=$.

Mangaliso, M. P. 2001. "Building Competitive Advantage from Ubuntu: Management Lessons from South Africa." Academy of Management Perspectives 15 (3): 23-33. https://doi.org/10.5465/ame.2001.5229453.

Masengwe, G. 2020. "The Church of Christ in Zimbabwe: Identity- and Mission-Continuity in Diversity." PhD thesis, Systematic Theology, Faculty of Social Sciences, Arts and Humanities, University of South Africa, Pretoria.

Masengwe, G., and F.H. Chimhanda. 2019. "Towards Authentic Transformation in the Church of Christ in Zimbabwe." HTS Theological Studies 74 (1): 1-11. https://doi.org/10.4102/hts.v75i1.4776.

Masengwe, G., F. H. Chimhanda, and R. Hove. 2019. "Women, Marginality and the Bible: Sexism in the Church of Christ in Zimbabwe," 278-289. BIAS 22: Bible in Africa Studies. Bamberg University Press.

Masengwe, G., and F. H. Chimhanda. 2020. "Postmodernism, Identity and Mission Continuity in the Church of Christ in Zimbabwe." Verbum et Ecclesia 40 (1): 1-10. https://doi.org/10.4102/ve.v41i1.1906.

Maxwell, D. 2013. "Freed Slaves, Missionaries, and Respectability: The Expansion of the Christian Frontier from Angola to Belgian Congo." The Journal of African History 54 (1): 79-102. https://doi.org/10.1017/S0021853713000030.

Mbigi, J., and J. Maree. 1995. Ubuntu: The Spirit of African Transformation Management. Randburg, South Africa: Knowledge Resources.

Mbigi, L. 1996. “Ubuntu: Spirit of African Solidarity.” Enterprise 62: 3 
McAlister, L.G., and W. E. Tucker. 1975. Journey in Faith: A History of the Christian Church (Disciples of Christ). St Louis: Chalice Press.

McLoughlin, W.G. 2013. Revivals, Awakening and Reform. Chicago: University of Chicago Press.

Mnyaka, M., and M. Motlhabi. 2005. "The African Concept of Ubuntu/Botho and its Sociomoral Significance.” Black Theology 3 (2): 215-237.

https://doi.org/10.1558/blth.3.2.215.65725.

Mofokeng, T. A. 1983. "The Crucified among the Cross-Bearers: Towards Black Christology." https://scholar.google.com/scholar?hl=en\&as_sdt=0\%2C5\&q=The+Crucified+among+the + Cross-Bearers\%3A+Towards+a+Black+Christology\&btnG $=$.

Moyana, R. 2017. Reading Our Past: A Historical Study of the White Authored Novel in Zimbabwe Ca 1890 to 1994: Content and Character. Africa Institute for Culture, Peace, Dialogue and Tolerance Studies.

Murithi, T. 2009. "An African Perspective on Peace Education: Ubuntu Lessons in Reconciliation.” International Review of Education 55 (2-3): 221-233. https://doi.org/10.1007/s11159-009-9129-0.

Ncube, L. B. 2010. "Ubuntu: A Transformative Leadership Philosophy.” Journal of Leadership Studies 4 (3): 77-82. https://doi.org/10.1002/jls.20182.

Nelson, L. 2004. "An Exploratory Study of the Application and Acceptance of Servantleadership Theory among Black Leaders in South Africa." PhD thesis. Regent University.

Ntibagirirwa, S. 2009. "Cultural Values, Economic Growth and Development.” Journal of Business Ethics 84 (3): 297-311. https://doi.org/10.1007/s10551-009-0203-0.

Nussbaum, B. 2003. "Ubuntu: Reflections of a South African on Our Common Humanity." Reflections 4 (4): 21-29. https://doi.org/10.1162/152417303322004175.

Nzimakwe. T. I. 2014. "Practising Ubuntu and Leadership for Good Governance. The South African and Continental Dialogue." African Journal of Public Affairs 7 (4): 30-52.

Qobo, M., and N. Nyathi. 2016. "Ubuntu, Public Policy Ethics and Tensions in South Africa's Foreign Policy.” South African Journal of International Affairs 23 (4): 421-436. https://doi.org/10.1080/10220461.2017.1298052.

Ramose. M. B. 1999. African Philosophy through Ubuntu. Harare: Mond Books.

Ramose, M. B. 2010. "The Death of Democracy and the Resurrection of Timocracy." Journal of Moral Education 39 (3): 291-303. 
Reese, R. 2007. "The Surprising Relevance of the Three-self Formula." Mission Frontiers 29 (4): 25-27.

Reese, R., and W. Wimon. 2001. A Survey of Work in Southern Africa 100 years of African Missions, Essays in Honour of Wendell Broom. Abilene: A.C.U Press.

Rukuni, M. 2007. Being African: Rediscovering the Traditional Unhu-Ubuntu-Botho: Pathways of being Human. Cape Town: Mandala Publishers.

Rushford, J. 1998. "Christians on the Oregon Trail: Churches of Christ and Christian Churches in Early Oregon, 1842-1882. Churches of Christ.” https://digitalcommons.pepperdine.edu.

Samkange, S. J. T. 1980. Hunhuism or Ubuntuism: A Zimbabwe Indigenous Political Philosophy. Harare: Graham Publishing.

Samkange, S. J. T. 1982. What Rhodes really Said about Africans. Harare: Zimbabwe Publishing House.

Thomas, A. 1997. Rhodes: The Race for Africa. Penguin.

Van der Merwe, W. L. 1996. "Philosophy and the Multi-Cultural Context of (Post) Apartheid South Africa." Ethical Perspectives 3 (2): 76-90. https://doi.org/10.2143/EP.3.2.563038.

Weber, M. 1978. The City. New York: The Free Press.

Weber, M. 2009. The Theory of Social and Economic Organization. New York: Simon and Schuster.

Williams, D. N., D. A. Foster, and P. M. Blowers. 2013. The Stone-Campbell Movement: A Global History. Nashville: Chalice Press.

Winston, C. 2007. Government Failure versus Market Failure: Microeconomics Policy Research and Government Performance. Brookings Institution Press.

Woodhouse, S. 2018. Garfield Todd: The End of the Liberal Dream in Rhodesia. Harare: Weaver Press. 